University of Nebraska - Lincoln

DigitalCommons@University of Nebraska - Lincoln

Agronomy \& Horticulture - Faculty Publications

Agronomy and Horticulture Department

May 2006

\title{
Chemical stabilization of soil organic nitrogen by phenolic lignin residues in anaerobic agroecosystems
}

\author{
D.C. Olk \\ USDA-ARS, National Soil Tilth Laboratory \\ Kenneth G. Cassman \\ University of Nebraska-Lincoln, kcassman1@unl.edu \\ K. Schmidt-Rohr \\ lowa State University, Ames, IA \\ M.M. Anders \\ University of Arkansas Rice Research and Extension Center \\ J.-D. Mao \\ Old Dominion University, Norfolk, VA
}

See next page for additional authors

Follow this and additional works at: https://digitalcommons.unl.edu/agronomyfacpub

Part of the Plant Sciences Commons

Olk, D.C.; Cassman, Kenneth G.; Schmidt-Rohr, K. ; Anders, M.M.; Mao, J.-D.; and Deenik, J.L., "Chemical stabilization of soil organic nitrogen by phenolic lignin residues in anaerobic agroecosystems" (2006). Agronomy \& Horticulture -- Faculty Publications. 12.

https://digitalcommons.unl.edu/agronomyfacpub/12

This Article is brought to you for free and open access by the Agronomy and Horticulture Department at DigitalCommons@University of Nebraska - Lincoln. It has been accepted for inclusion in Agronomy \& Horticulture -Faculty Publications by an authorized administrator of DigitalCommons@University of Nebraska - Lincoln. 
Authors

D.C. Olk, Kenneth G. Cassman, K. Schmidt-Rohr, M.M. Anders, J.-D. Mao, and J.L. Deenik 


\title{
Chemical stabilization of soil organic nitrogen by phenolic lignin residues in anaerobic agroecosystems
}

\author{
D.C. Olk ${ }^{\mathrm{a}, *}$, K.G. Cassman ${ }^{\mathrm{b}}$, K. Schmidt-Rohr ${ }^{\mathrm{c}}$, M.M. Anders ${ }^{\mathrm{d}}$, J.-D. Mao ${ }^{\mathrm{e}}$, J.L. Deenik ${ }^{\mathrm{f}}$ \\ ${ }^{a}$ USDA-ARS, National Soil Tilth Laboratory, 2150 Pammel Drive, Ames, IA 50011, USA \\ ${ }^{\mathrm{b}}$ Department of Agronomy and Horticulture, University of Nebraska, Lincoln, NE 68583, USA \\ ${ }^{\mathrm{c}}$ Department of Chemistry, Iowa State University, Ames, IA 50011, USA \\ ${ }^{\mathrm{d}}$ University of Arkansas Rice Research and Extension Center, 2900 Hwy 130E, Stuttgart, AR 72160, USA \\ ${ }^{\mathrm{e}}$ Department of Chemistry and Biochemistry, Old Dominion University, Norfolk, VA 23529, USA \\ ${ }_{\mathrm{f}}^{\mathrm{f}}$ Department of Tropical Plant and Soil Sciences, University of Hawaii, 3190 Maile Way, St. John 102, Honolulu, HI 96822, USA
}

Available online 9 May 2006

\begin{abstract}
This review summarizes independent reports of yield decreases in several agricultural systems that are associated with repeated cropping under wet or submerged soil conditions. Crop and soil data from most of these agroecosystems have led researchers to attribute yield decreases to a reduction in crop uptake of $\mathrm{N}$ mineralized from soil organic matter (SOM). These trends are most evident in several long-term field experiments on continuous lowland rice systems in the Philippines, but similar trends are evident in a continuous rice rotation in Arkansas, USA and with no-till cropping systems in North American regions with cool, wet climatic conditions in Spring. Soil analyses from some of these systems have found an accumulation of phenolic lignin compounds in SOM. Phenolic compounds covalently bind nitrogenous compounds into recalcitrant forms in laboratory conditions and occurrence of this chemical immobilization under field conditions would be consistent with field observations of reduced soil N supply. However, technological shortcomings have precluded its demonstration for naturally formed SOM. Through recent advances in nuclear magnetic resonance spectroscopy, agronomically significant quantities of lignin-bound $\mathrm{N}$ were found in a triple-cropped rice soil in the Philippines. A major research challenge is to demonstrate in the anaerobic agroecosystems that these lignin residues bind sufficient quantities of soil $\mathrm{N}$ to cause the observed yield decreases. A key objective will be to elucidate the cycling dynamics of lignin-bound $\mathrm{N}$ relative to the seasonal pattern of crop $\mathrm{N}$ demand. Anaerobic decomposition of crop residues may be the key feature of anaerobic cropping systems that promotes the accumulation of phenolic lignin residues and hence the covalent binding of soil N. Potential mitigation options include improved timing of applied $\mathrm{N}$ fertilizer, which has already been shown to reverse yield decreases in tropical rice, and aerobic decomposition of crop residues, which can be accomplished through field drainage or timing of tillage operations. Future research will evaluate whether aerobic decomposition promotes the formation of phenol-depleted SOM and greater in-season $\mathrm{N}$ mineralization, even when the soil is otherwise maintained under flooded conditions during the growing season.
\end{abstract}

(C) 2006 Elsevier Ltd. All rights reserved.

Keywords: Anaerobic; Lignin; Nitrogen; NMR; Soil organic matter; Phenols; Rice

\section{Introduction}

Soil organic matter (SOM) contains the vast majority of $\mathrm{C}, \mathrm{N}, \mathrm{P}$ and $\mathrm{S}$ that are found in soil. Its chemical nature is thought to influence the storage and release of these essential nutrients into plant-available forms. Yet evidence for such an influence is sparse, largely due to the inability

\footnotetext{
${ }^{*}$ Corresponding author. Tel.: + 15152948412 ; fax: + 15152948125.

E-mail address: olk@nstl.gov (D.C. Olk).
}

to determine the exact chemical nature of SOM (MacCarthy, 2001) or even the bonding environments of SOM-bound nutrients. Recent studies have identified the accumulation of phenolic compounds in the SOM of submerged soils that were intensively cropped to irrigated lowland rice (Oryza sativa L.) in the Philippines (Olk et al., 1996, 1998). Using newly developed analytical techniques to identify the bonding environments of $\mathrm{C}$ with $\mathrm{N}$, phenolic lignin residues were shown to have bound covalently with $\mathrm{N}$ in a humic acid fraction (Schmidt-Rohr et al., 2004). The 
resulting chemical stabilization was hypothesized to have contributed to an observed long-term decrease in availability of soil $\mathrm{N}$ and an associated decline in rice grain yield. In this review we summarize the concepts gained from this study of continuous cultivation to irrigated lowland rice, and we report independent observations from other agroecosystems in which soil remains anaerobic or partly anaerobic during the year and for which soil data suggest the covalent binding of soil $\mathrm{N}$ by lignin residues.

\section{Intensive lowland rice cropping in tropical Asia}

\subsection{Yield trends and SOM quality under intensive rice cropping}

During the Green Revolution of the 1960s, plant breeders developed early maturing semi-dwarf varieties of lowland rice that allow two or even three rice crops per year on the same field. Since then, these annual double- and triple-cropped continuous rice systems have become the dominant agricultural land use in the tropical and subtropical lowlands of Asia wherever irrigation water supplies are adequate. This intensive cropping system enabled the Asian rice supply to keep pace with burgeoning populations, as irrigated lowland rice farmers account for about three-quarters of Asia's rice supply (Cassman and Pingali, 1995).

Under intensive cropping, lowland rice soils are submerged for 8-11 months each year. During development of the semi-dwarf varieties in the 1960s, concerns arose over the sustainability of the long-term submerged soil conditions that would accompany continuous cropping. Longterm field experiments were initiated to monitor soil properties under double- and triple-cropped rice. During the subsequent decades, yields gradually declined in some of these long-term experiments (Cassman et al., 1995; Dobermann et al., 2000). For example, in a triple-cropped field trial at the International Rice Research Institute (IRRI) in the Philippines, yields declined during $24 \mathrm{y}$ by 3 ton/ha in the high-yielding dry season and about 2 ton/ha in each of the two wet seasons, or $38 \%$ and about $50 \%$, respectively, of the initial yields. There was no evidence for uniform occurrence of pest damage (insects, disease, weeds, nematodes) that would cause this gradual yield decline (Cassman et al., 1995). Phosphorus, $\mathrm{K}$ and $\mathrm{Zn}$ fertilizers were applied at non-limiting rates, and plant tissue nutrient concentrations excluded any role of boron toxicity. Crop growth characteristics and plant $\mathrm{N}$ status suggested that $\mathrm{N}$ deficiency during mid- to late-season growth stages contributed to the yield decline. Yet crop response to fertilizer $\mathrm{N}$ applications at early crop growth stages had changed little. Based on these trends, Cassman et al. (1995) attributed the yield decline to decreased crop uptake of native soil $\mathrm{N}$, namely soil organic $\mathrm{N}$ that becomes available through mineralization of soil organic matter. However, the quantity of soil $\mathrm{N}$ in these field experiments had not decreased and in fact had even increased since these experiments were initiated, which focused research efforts on possible changes in the quality of SOM under long-term submerged conditions.

These views were based on the unique nature of $\mathrm{N}$ cycling in flooded soil. Inorganic $\mathrm{N}$ is not stable in flooded soils for more than a few weeks, as nitrification does not occur and $\mathrm{NH}_{4}$ is rapidly lost, primarily through $\mathrm{NH}_{3}$ volatilization when the floodwaters become alkaline. The floodwater $\mathrm{pH}$ can increase by as much as two units following urea hydrolysis or photosynthesis by floodwater microorganisms (Keeney and Sahrawat, 1986; Reddy et al., 1990). During the years of declining yields in the long-term field experiments, most fertilizer $\mathrm{N}$ (urea) was applied in one or two applications at early season crop growth stages. Given a 90- to 100-day growing season, consequently, crop $\mathrm{N}$ uptake at later growth stages was dependent solely on mineralization of soil organic $\mathrm{N}$, and development of a late-season $\mathrm{N}$ deficiency suggests an inhibition of soil $\mathrm{N}$ mineralization.

In the 1990s, grain yields of the triple-cropped field experiment were restored to their initial levels, in part because of greater solar radiation but also because of more numerous applications of $\mathrm{N}$ fertilizer throughout the growing season and at higher overall rates, providing better synchrony between $\mathrm{N}$ supply and crop $\mathrm{N}$ demand (Cassman et al., 1995; Dobermann et al., 2000). This yield reversal provided further evidence that changes in soil $\mathrm{N}$ supply had contributed to the yield decline.

Assuming a physiological efficiency of $50 \mathrm{~kg}$ grain $/ \mathrm{kg} \mathrm{N}$ uptake (Yoshida, 1981), the yield loss in the triple-cropped field was equivalent to a decrease in crop uptake of about $60 \mathrm{~kg} \mathrm{~N} /$ ha season. This quantity is a large proportion of the fertilizer rates that tropical rice farmers typically apply each season (generally $90-150 \mathrm{~kg} / \mathrm{ha}$ ), but it is not a significant proportion of total soil $\mathrm{N}$ in the plow layer of the triple-cropped field (2000-3000 kg N/ha). The cause of this substantial yield decline may therefore involve solely a portion of the SOM.

A clear change in the chemical nature of SOM that occurs under intensive rice cropping is the accumulation of phenolic compounds (Olk et al., 1996, 1998, 1999, 2000). The dominant types of phenols detected in rice soils (cinnamyl, syringyl and vanillyl) are derived from plant lignin, which comprises the woody tissues of crop roots and straw. More broadly, phenols accumulate in many anaerobic environments, including streams (Malcolm, 1990) and natural wetlands (Katase, 1993). Anaerobic conditions slow decomposition of many organic materials, but lignin and phenols are especially affected (Tate, 1979; Colberg, 1988). Anaerobic bacteria do not have suitable enzymes for rapid degradation of lignin. Their decomposition pathways of aromatic compounds involve slower and less efficient reactions than those of aerobic microorganisms (Evans, 1977). Concurrent with the slowed rate of lignin decomposition under multiple annual cropping of rice, the input rates of lignin are increased because crop residues and roots are returned to the soil two to three 
times annually compared to the previous practice of one annual crop using traditional, long-maturing rice varieties. Although lignin does degrade in anaerobic soils at detectable rates (Benner et al., 1984), the rate under intensive rice cropping is apparently not sufficient to offset the elevated rates of residue input.

In laboratory studies of model compounds, phenolic compounds covalently bind nitrogenous compounds into recalcitrant forms (Mortland and Wolcott, 1965; Flaig et al., 1975; Haider et al., 1975). Nitrogen in the resulting anilide-like structure (Fig. 1) would be less easily mineralized into an available form than is the more common $\mathrm{N}$ form of amino N (Verma et al., 1975; Stevenson and Cole, 1999) especially under the anoxic conditions of submerged soils. Although phenolic binding of $\mathrm{N}$ has been demonstrated for model compounds under laboratory conditions, some researchers have doubted the occurrence of this covalent binding in field conditions: for years studies failed to find evidence for anilide $\mathrm{N}$ or other forms of aromatic $\mathrm{N}$ in SOM that formed under natural conditions, even when using leading analyses for the chemical structure of SOM such as cross polarization/magic angle spinning ( $\mathrm{CP} / \mathrm{MAS})$ ${ }^{15} \mathrm{~N}$ nuclear magnetic resonance (NMR) spectroscopy, (Preston, 1996; Knicker and Hatcher, 1997; Knicker and Kögel-Knabner, 1998).

Improved detection of lignin residue-bound $\mathrm{N}$ became possible when Schmidt-Rohr and Mao (2002a) developed saturation-pulse-induced dipolar exchange with recoupling (SPIDER), an NMR technique involving MAS for selective detection of carbons that are bonded to N. In the center of a sequence of rotation-synchronized $180^{\circ}$ pulses on the ${ }^{13} \mathrm{C}$ spins, which recouples the ${ }^{14} \mathrm{~N}-{ }^{13} \mathrm{C}$ dipolar interaction that would otherwise be averaged out by MAS, the ${ }^{14} \mathrm{~N}$ coherences are saturated by a train of small-angle ${ }^{14} \mathrm{~N}$ pulses for $1-2 \mathrm{~ms}$. This provides efficient partial dipolar dephasing of ${ }^{13} \mathrm{C}$ bonded to ${ }^{14} \mathrm{~N}$, at MAS frequencies that permit detection of aromatic carbon resonances with sufficient sensitivity. The difference between the dephased and undephased ${ }^{13} \mathrm{C}$ NMR spectra shows only carbons connected to nitrogen. Other NMR spectral editing methods separate overlapping resonances

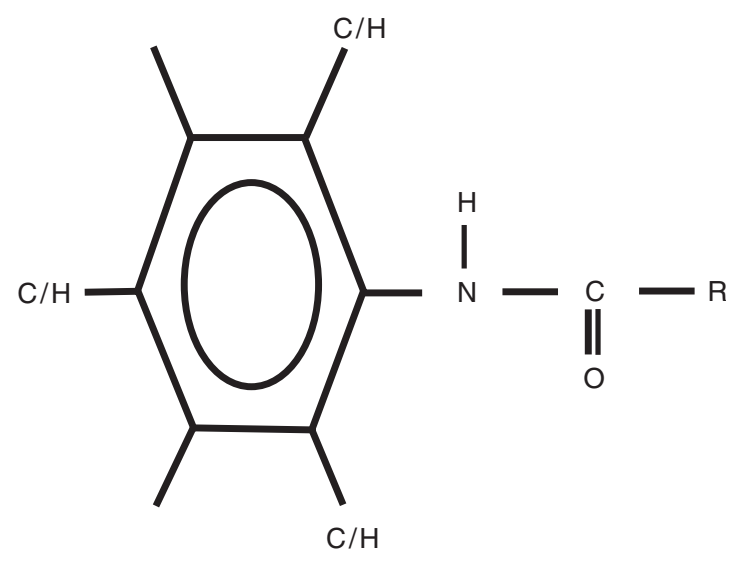

Fig. 1. Chemical structure of anilide.

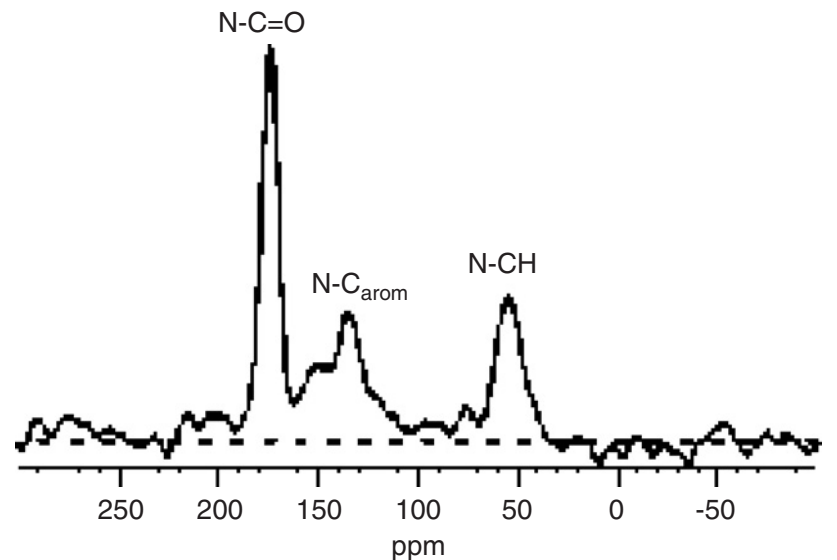

Fig. 2. Solid-state $\left\{{ }^{14} \mathrm{~N}-\right\}^{13} \mathrm{C}$ NMR spectrum of the mobile humic acid fraction from a triple-cropped rice soil, obtained by using the SPIDER technique. The amide (NCO) peak is at $174 \mathrm{ppm}$, and the peak for anilide $\mathrm{N}\left(\mathrm{N}-\mathrm{C}_{\text {arom }}\right)$ is at $134 \mathrm{ppm}$. Aliphatic $\mathrm{NCH}$ resonances of peptides are at $55 \mathrm{ppm}$. Reprinted with permission from Schmidt-Rohr et al. (2004).

of various chemical groups (Schmidt-Rohr and Mao, 2002b). The method has been tested and calibrated on model compounds (Schmidt-Rohr and Mao, 2002a).

Schmidt-Rohr et al. (2004) used SPIDER to identify agronomically significant quantities of anilide $\mathrm{N}$ in the mobile humic acid (MHA) fraction - a young, lignin-rich humic fraction - that was extracted from the triple-cropped rice soil at IRRI (Fig. 2). Anilide- $\mathrm{N}$ caused the $\mathrm{N}-\mathrm{C}_{\text {arom }}$ resonance around $134 \mathrm{ppm}$, and it also provided an equally strong contribution to the $\mathrm{N}-\mathrm{C}=\mathrm{O}$ peak near $173 \mathrm{ppm}$. Anilide- $\mathrm{N}$ accounted for $25 \%$ of total $\mathrm{N}$ in the MHA fraction. The excess quantity of anilide- $\mathrm{N}(55 \mathrm{~kg} \mathrm{~N} / \mathrm{ha})$ in this fraction compared to the MHA fraction of a nearby aerated rice soil was similar to the historical decrease in crop uptake of soil $\mathrm{N}(60 \mathrm{~kg} \mathrm{~N} /$ ha season) that was associated with the yield decline. Hence the slower mineralization of anilide $\mathrm{N}$ could contribute substantially to the decreased availability of soil N. Schmidt-Rohr et al. (2004) concluded that anilide $\mathrm{N}$ formed from phenolic lignin residues, based on the chemical properties of the aromatic portion of the anilide and because the abundance of anilide in three SOM fractions was proportional to the abundance of lignin residues. Their findings represent the first direct evidence for covalent binding of $\mathrm{N}$ by phenolic lignin residues in naturally formed SOM.

\subsection{Anaerobic decomposition of crop residues}

Additional NMR analyses suggested that the key trait of intensive rice cropping that promotes the accumulation of phenolic lignin residues - and consequently covalent binding of $\mathrm{N}$-may be anaerobic decomposition of crop residues (Olk et al., 1998). For a double-cropped rice experiment that was conducted at three sites in the Philippines, spectra of ${ }^{13} \mathrm{C} \mathrm{CP} /$ MAS NMR documented the presence of phenols in the MHA fraction at all sites, despite large differences among the sites in the degree of 
soil drying during the fallow periods. The degree of soil drying at each site reflected local rainfall amount and pattern. At IRRI (Fig. 3a), the soil dried to air-dryness on the surface during the first fallow and remained wet throughout the second fallow. At the Philippine Rice Research Institute (PRRI), the surface soil dried to airdryness during both fallows and also at depth during the second fallow at the beginning of the dry season (Fig. 3b). Yet grain yields declined at both sites (Cassman et al., 1995). A common practice at both sites - and in fact a customary step in Asian rice production -was the incorporation of crop residues into the soil at the end of each fallow period, when soil is flooded to facilitate its tillage by the puddling operation, followed by transplanting of the next crop. Thus the incorporated crop residues decompose under anaerobic soil conditions. Because crop residues are the primary parent material of new SOM, the anaerobic decomposition could affect the chemical nature of young SOM independently of the annual duration of flooding.

Despite similar amounts of crop residue returned at both sites, SOM decomposed faster in the better aerated PRRI

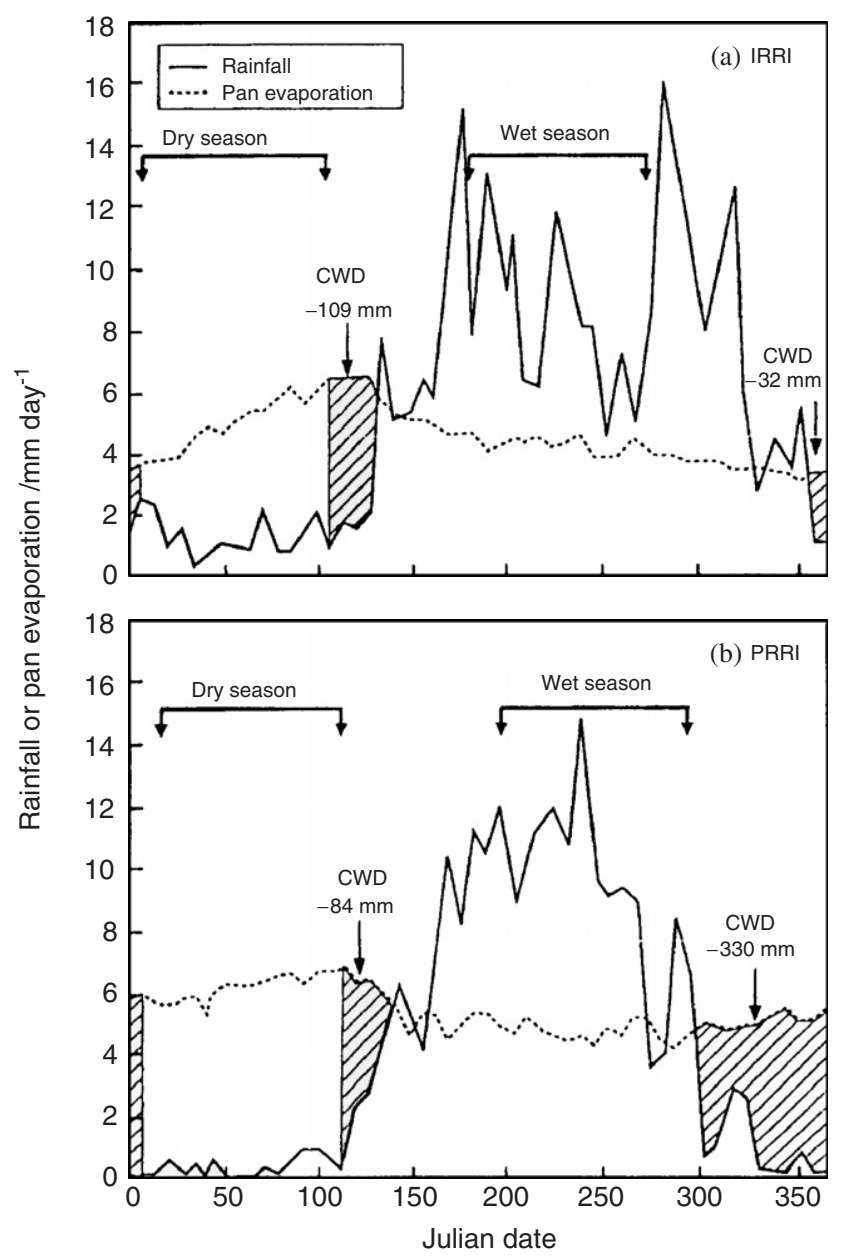

Fig. 3. Annual patterns of rainfall and pan evaporation at (a) the International Rice Research Institute (IRRI) and (b) Philippine Rice Research Institute (PRRI). Cumulative water deficits (CWD) are shown as hatched areas. Reprinted from Olk et al. (1998) with permission of Blackwell Publishing. soil, as soil organic $\mathrm{C}$ was a third less than in the IRRI soil (Olk et al., 1998). The MHA fraction of the PRRI soil had only one-third the mass of the MHA pool extracted from the IRRI soil, and it was composed of extremely young compounds, including high concentrations of total $\mathrm{N}$ and amide $\mathrm{N}$ as determined by $\mathrm{CP} / \mathrm{MAS}{ }^{15} \mathrm{~N}$ NMR (Mahieu et al., 2000). By comparison, the chemical nature of the MHA from the IRRI soil suggested the presence of older, more humified materials in addition to the young materials that comprised the MHA fraction of the PRRI soil. Accordingly, $\mathrm{N}$ mineralization from the PRRI MHA was $48 \%$ greater than from the IRRI MHA when these MHA fractions were added in equal amounts to two rice soils and incubated for 42 days (Nguyen et al., 2004), indicating that partial aeration of rice soils can lead to higher quality SOM that is more readily mineralizable.

To further evaluate this hypothesis, anaerobic decomposition of crop residues was compared with aerobic decomposition in a field experiment at IRRI beginning in 1995. Soil phenol accumulation and in-season N mineralization were measured during a 4-year period of doublecropped rice (Olk et al., 2006). At transplanting of the wet season crop in the $3 \mathrm{rd}$ year, ${ }^{15} \mathrm{~N}$-enriched urea fertilizer was applied to microplots that were imbedded within main plots and at the same rate that unlabeled urea fertilizer was applied outside the microplots. One week later, the amount of fertilizer $\mathrm{N}$ that had been immobilized into the MHA fraction was similar for both anaerobic and aerobic residue decomposition treatments. During the rest of the growing season, $45 \%$ of this immobilized fertilizer $\mathrm{N}$ was remineralized from the MHA of the aerobic decomposition treatment, but none was remineralized from the MHA of the anaerobic decomposition treatment. Mineralization of total $\mathrm{N}\left({ }^{14} \mathrm{~N}\right.$ and $\left.{ }^{15} \mathrm{~N}\right)$ from the MHA fraction during the growing season was $22 \mathrm{~kg} \mathrm{~N} / \mathrm{ha}$ more with the aerobic residue decomposition treatment than with anaerobic decomposition. This difference was $20-25 \%$ of the crop $\mathrm{N}$ uptake that was normally achieved in this field experiment (data not shown). It was also $11 \%$ of the total $\mathrm{N}$ remaining in the MHA fraction of the anaerobic decomposition treatment shortly before crop harvest.

During the 4-year experiment the phenolic content of the MHA fraction gradually became enriched in the anaerobic decomposition treatment compared to aerobic decomposition (Fig. 4). Hence anaerobic decomposition of crop residues was associated with both inhibited mineralization of soil $\mathrm{N}$ and phenol enrichment. In the same field trial, this association was less apparent in the better-aerated conditions of a rice-maize (Zea mays L.) rotation than in the continuous rice rotation (data not shown). Nitrogen mineralization from a humic fraction that had a lower phenol content than the MHA fraction was less inhibited by anaerobic decomposition than was $\mathrm{N}$ mineralization from the MHA fraction (Olk et al., 2006), again illustrating the paired nature of inhibited $\mathrm{N}$ mineralization and phenol accumulation. The inhibition of $\mathrm{N}$ mineralization did not affect grain yield in this field experiment because $\mathrm{N}$ 
fertilizer was applied multiple times during each growing season to match the pattern of crop $\mathrm{N}$ demand; this synchronization would compensate for decreased availability of soil N (Cassman et al., 1995).

\section{Continuous rice rotation in Arkansas, USA}

In the Grand Prairie region of eastern Arkansas, the conventional crop rotation is an alternate year rice-soybean (Glycine $\max$ (L.) Merr.) rotation. Recent developments in availability of irrigation water and the appearance of soybean rust (Phakopsora pachyrhizi) in the U.S. South might promote continuous cropping of rice, at least in fields near water bodies. Increased SOM levels under continuous rice cropping might also improve soil

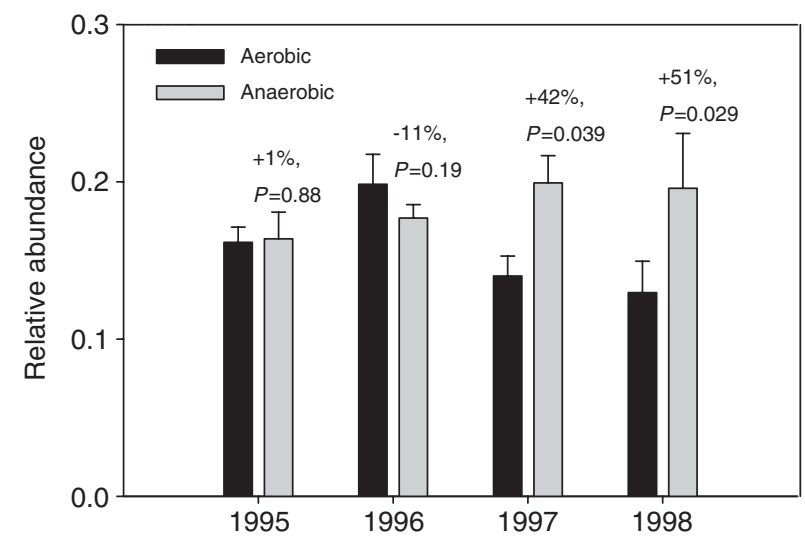

Fig. 4. Relative abundance of 2-methoxyphenol in the mobile humic acid fraction for aerobic decomposition of crop residues and anaerobic decomposition of crop residues during a four-year field experiment in the Philippines. Percent increase in relative abundance from aerobic to anaerobic decomposition and level of significance of this difference are indicated. Standard errors are indicated above each bar. Both treatments had two annual crops of lowland rice and high rates of $\mathrm{N}$ fertilizer application. Phenols were measured by tetramethylammonium hydroxide thermochemolysis, and relative abundance was calculated as the ratio of the peak area for 2-methoxyphenol to the peak area for an internal standard that was added to each sample. Statistical significance was determined at each sampling date through analysis of variance using a general linear model program that was appropriate to the split-plot field design. physical properties, thereby mitigating long-term degradation under the rice-soybean rotation (Scott and Wood, 1989). In a 4-yr field trial, however, grain yield of a continuous rice rotation was $19 \%$ (1.5 ton/ha) less than the grain yield of rice following soybean (Anders et al., 2004). Similar to the Philippines yield decline, agronomic symptoms of the yield gap indicated an $\mathrm{N}$ deficiency at later crop growth stages. Specifically, crop growth in early growth stages was healthy and similar for both crop rotations. After the green ring stage, however, during the transition from vegetative growth to reproductive growth stages, crop growth slowed for the continuous rice plants. Leaf tissue $\mathrm{N}$ concentration at this time decreased faster for continuous rice than for rice following soybean (data not shown), and fewer grains formed on plants under continuous rice cropping. No evidence was gained that suggested the yield gap was caused by pests (insects or diseases) or any other nutrient deficiency or toxicity, other than $\mathrm{N}$ deficiency. Following local recommendations, all fertilizer $\mathrm{N}$ was applied early in the growing season as a single pre-flood application at the fourth leaf growth stage.

In 2002, at the customary application time (41 days after seedling emergence) ${ }^{15} \mathrm{~N}$-enriched fertilizer was applied to microplots that were imbedded within crop rotation main plots that were all planted to rice. At the green ring growth stage, rice following soybean had taken up slightly more fertilizer ${ }^{15} \mathrm{~N}$ and also slightly more unlabeled $\mathrm{N}$, presumably mineralized from SOM, than did the continuous rice rotation (Table 1). During the remainder of the season, when the continuous rice plants became visibly $\mathrm{N}$ deficient, their uptake of fertilizer ${ }^{15} \mathrm{~N}$ continued at a slightly slowed rate but their uptake of unlabeled $\mathrm{N}$ lagged considerably further behind that of rice following soybean, suggesting decreased soil $\mathrm{N}$ mineralization in the continuous rice rotation.

In-season degradation of soil phenols also slowed under the continuous rice rotation. The enrichment of ligninderived phenols in the continuous rice soil compared to rice following soybean became more pronounced by shortly before harvest than early in the growing season (Fig. 5). Recent data from the 2004-growing season confirm the 2002 trends for both phenol enrichment and crop N uptake

Table 1

Crop uptake $(\mathrm{kg} / \mathrm{ha})$ of fertilizer $\mathrm{N}$ and soil $\mathrm{N}$ at two crop growth stages for two crop rotations in Stuttgart, Arkansas, 2002

\begin{tabular}{llcr}
\hline N pool & Rotation & Green ring $\left(83 \mathrm{DAE}^{\mathrm{a}}\right)$ & Pre-Harvest $(126$ DAE) \\
\hline Fertilizer & Rice-soybean & $59(6)$ & $54(4)$ \\
& Rice-rice & $52(3)$ & $40(4)$ \\
& Difference & $7(P=0.20)$ & $14(P=0.04)$ \\
Soil & Rice-soybean & $50(2)$ & $101(9)$ \\
& Rice-rice & $38(6)$ & $67(5)$ \\
& Difference & $12(P=0.27)$ & $34(P=0.02)$ \\
\hline
\end{tabular}

Standard errors are in parentheses.

Statistical significance $(P)$ was determined at each sampling date through analysis of variance using a general linear model program that was appropriate to the split-plot field design.

${ }^{\mathrm{a}}$ Days after emergence. 

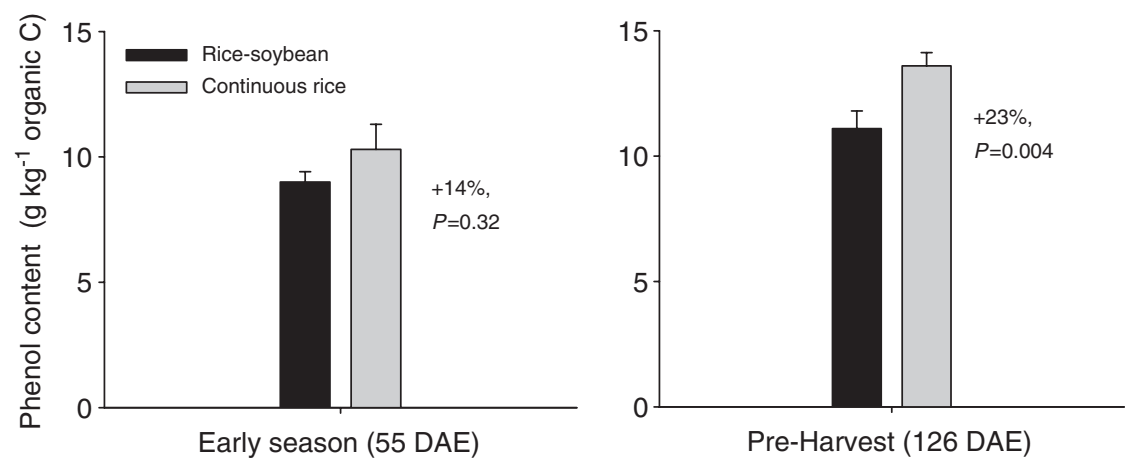

Fig. 5. Soil content of lignin-derived phenols (sum of coumaryl, syringyl and vanillyl phenols) extracted by cupric oxide analysis for rice-soybean and continuous rice rotations at two sampling dates during the 2002 rice growing season in Stuttgart, Arkansas. DAE is days after emergence. Percent increase from the rice-soybean rotation to continuous rice rotation and level of significance $(P)$ of this difference are indicated. Standard errors are indicated above each bar. Statistical significance was determined at each sampling date through analysis of variance using a general linear model program that was appropriate to the split-plot field design.

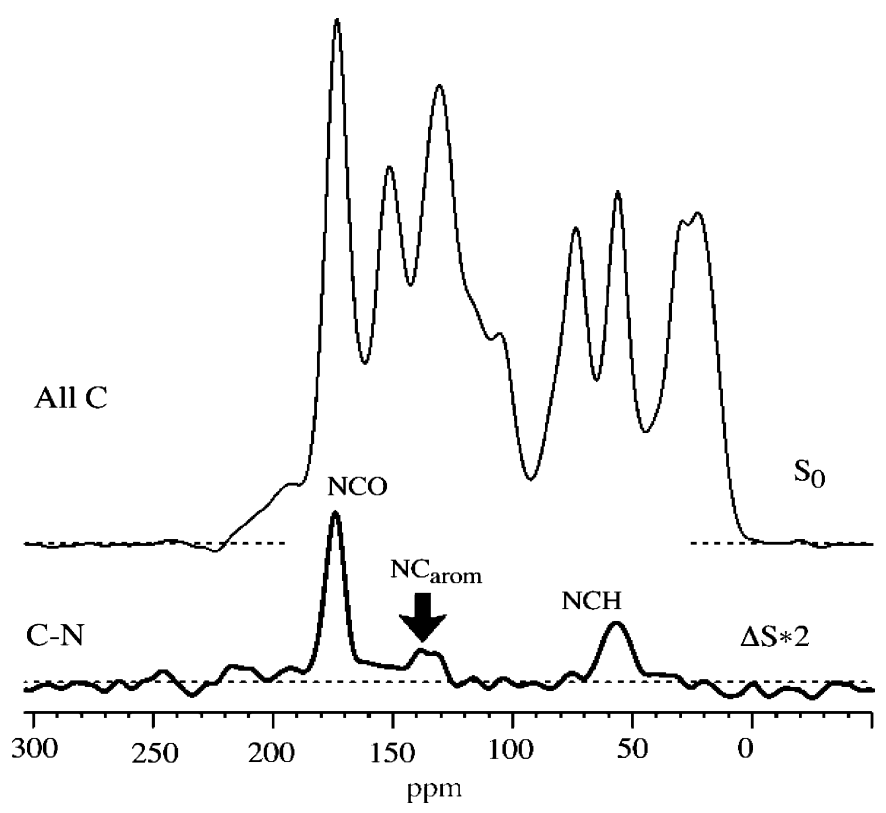

Fig. 6. Preliminary SPIDER $\left\{{ }^{14} \mathrm{~N}-\right\}^{13} \mathrm{C}$ NMR spectrum (bottom) and full reference spectra (top) of the mobile humic acid fraction that was extracted from an Arkansas soil under a continuous rice rotation. The amide $(\mathrm{NCO})$ peak is at $174 \mathrm{ppm}$, and the peak for anilide $\mathrm{N}\left(\mathrm{N}-\mathrm{C}_{\text {arom }}\right)$ is at $134 \mathrm{ppm}$ (marked by arrow). Aliphatic $\mathrm{NCH}$ resonances of peptides are at $55 \mathrm{ppm}$.

(data not shown). Analysis by SPIDER of the MHA fraction from the continuous rice rotation demonstrated the presence of anilide N (Fig. 6). In summary, yield reduction in the continuous rice rotation appears to be caused by an $\mathrm{N}$ deficiency, which resulted from a decrease in mid-season uptake of soil $\mathrm{N}$. The inhibition of $\mathrm{N}$ mineralization, in other words a relative accumulation of soil $\mathrm{N}$, was associated with a simultaneous accumulation of soil phenols. Hence, similar to the Philippines studies of intensive rice cropping, the yield reduction in the Arkansas continuous rice system was associated with accumulation of both soil $\mathrm{N}$ and phenols.

\section{Taro in Hawaii, USA}

Taro (Colocasia esculenta L.) is commonly grown under paddy conditions, in which floodwaters are maintained in the field for as many as 13 consecutive months. Paddy taro is normally grown continuously, and fallows between crops are of short duration. Taro is harvested for starch that accumulates in the corm, a thickened section of the root. In Hawaii, the statewide mean taro yield declined from 24.8 to 18.4 ton/ha between 1965 and 1979 (U.S. Department of Agriculture 1975, 1980). Long-term yield trends for individual fields have not been recorded, and it is unknown whether the yield decline is due to nutrient disorders, pest damage, or other causes. Anecdotal evidence suggests an $\mathrm{N}$ deficiency, despite monthly applications of $\mathrm{N}$ fertilizer. A small signal for anilide $\mathrm{N}$ was detected by SPIDER analysis of the MHA fraction from a farmer's taro soil in Kauai (Fig. 7). Future work will establish the taro yield response to more frequent application of $\mathrm{N}$ fertilizer. Seasonal patterns of crop $\mathrm{N}$ uptake and yields for farmers' fields that differ in the intensity of previous taro production will be compared to the chemical nature of SOM extracted from soils in those fields.

\section{No-tillage in temperate climates}

In temperate regions, fields are commonly tilled soon after harvest to promote decomposition of crop residues, which probably occurs largely in the autumn. Under notillage, crop residue decomposition is delayed further into the next growing season because the crop residues remain at or near the soil surface. In many temperate regions, abundant springtime precipitation saturates the soil for extended periods of time. Consequently, the soils are anoxic, and the underlying layers of the surface crop residue layer can decompose to some degree under anaerobic conditions. Yield gaps are also common with no-tillage, especially in poorly drained soils (Iragavarapu and Randall, 1995). In several North American studies 


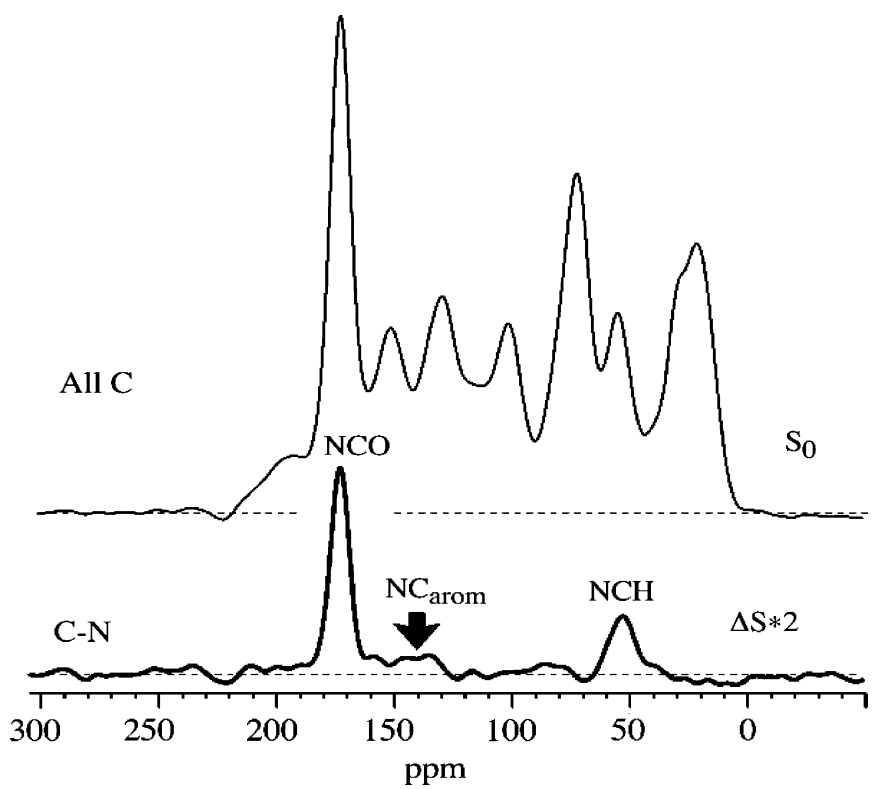

Fig. 7. Preliminary SPIDER $\left\{{ }^{14} \mathrm{~N}-\right\}^{13} \mathrm{C}$ NMR spectrum (bottom) and full reference spectra (top) of the mobile humic acid fraction that was extracted from a Hawaii taro soil The amide (NCO) peak is at $174 \mathrm{ppm}$, and the peak for anilide $\mathrm{N}\left(\mathrm{N}-\mathrm{C}_{\text {arom }}\right)$ is at $134 \mathrm{ppm}$ (marked by arrow). Aliphatic NCH resonances of peptides are at $55 \mathrm{ppm}$.

Table 2

Studies in temperate climates that found an inhibition of no-tillage on availability of soil $\mathrm{N}$ or immobilized fertilizer ${ }^{15} \mathrm{~N}$.

\begin{tabular}{ll}
\hline Citation & Crop/location \\
\hline Carefoot et al. (1990) & Wheat-barley/Alberta \\
Clay et al. (1990) & Corn/Minnesota \\
Kitur et al. (1984) & Corn/Kentucky \\
Meisinger et al. (1985) & Corn/Maryland \\
Rice et al. (1986) & Corn/Kentucky \\
\hline
\end{tabular}

involving different no-tilled crops, ${ }^{15} \mathrm{~N}$-enriched fertilizer was added to distinguish fertilizer $\mathrm{N}$ from mineralized soil $\mathrm{N}$ (Table 2). Uptake or mineralization of unlabeled $\mathrm{N}$, presumably mineralized from SOM, was less with notillage than with conventional tillage, while crop uptake of fertilizer $\mathrm{N}$ was less impaired by no-tillage. At some locations, decreased availability of soil $\mathrm{N}$ was associated with a loss of crop yield. In other studies lacking labeled fertilizer, symptoms of $\mathrm{N}$ deficiency were more evident in no-tilled crops than with conventional tillage (Thomas et al., 1973; Bandel et al., 1975). To date the effects of notillage on the chemical nature of SOM have received little attention. We are planning research that will investigate whether phenolic lignin residues accumulate under notillage and whether they covalently bind soil $\mathrm{N}$, causing a decrease in $\mathrm{N}$ mineralization. Alternatively, the yield gap that is associated with no-tillage might be caused partly or entirely by lower soil temperature, temporary biological $\mathrm{N}$ immobilization (Balesdent et al., 2000), or mechanical impedance, and in poorly drained soils by inadequate aeration for nutrient uptake, allelopathy, pathogens, or poor seedling establishment (Cannell and Hawes, 1994; Iragavarapu and Randall, 1995).

\section{Discussion}

In this review, cropping systems in which soil remains anaerobic for substantial periods of time were found to share a common trend of yield declines or yield gaps. The yield problems were frequently associated with insufficient crop uptake of mineralized soil $\mathrm{N}$, even when total soil $\mathrm{N}$ content remained constant or increased and crop uptake of fertilizer $\mathrm{N}$ was less affected by the submerged conditions. A fundamental distinction of anaerobic agroecosystems from aerobic agroecosystems is the rapid loss of inorganic $\mathrm{N}$ forms from the soil, due primarily to ammonia volatilization. Consequently, provision of a steady $\mathrm{N}$ supply to the crop is more difficult in anaerobic soils, and any decrease in SOM quality that reduces soil $\mathrm{N}$ mineralization is more likely to negatively affect crop $\mathrm{N}$ uptake and yields than in aerated soils, where inorganic $\mathrm{N}$ forms are more stable during the growing season. Maintenance of a steady and sufficient $\mathrm{N}$ supply is especially pivotal at high yield targets, when crop growth is more likely to be limited primarily by $\mathrm{N}$.

A frequent characteristic of these anaerobic agroecosystems is the accumulation of phenolic lignin residues in the SOM. Although phenols are known to covalently bind organic $\mathrm{N}$ in laboratory studies, demonstrating the occurrence of this chemical stabilization under field conditions has been a challenging first step toward resolving the $\mathrm{N}$ deficiencies and yield decreases. With development of the SPIDER technique, it is now possible to measure the abundance of lignin residue-bound $\mathrm{N}$ in SOM that formed under field conditions. The new issue is whether the chemical stabilization affects agronomically significant quantities of $\mathrm{N}$ and is primarily responsible for the yield decreases in the anaerobic agroecosystems.

\subsection{Agronomic significance of covalently bound $N$}

If strongly bound nutrient forms such as anilide $\mathrm{N}$ were never mineralized, then total soil $\mathrm{N}$ would increase indefinitely as long as conditions favor the chemical binding of $\mathrm{N}$ with lignin residues. In long-term field experiments of lowland rice in the Philippines, total soil $\mathrm{N}$ increased during the initial years of intensive cropping, but it eventually stabilized at elevated levels (De Datta et al., 1988), suggesting the resumption of significant $\mathrm{N}$ mineralization. Future research will explore the hypothesis that covalent binding of $\mathrm{N}$ into stable forms such as anilide slows the rate of $\mathrm{N}$ mineralization while also extending its duration into late season crop growth stages and the subsequent fallow period. As long as the field remains flooded, mineralization of covalently bound $\mathrm{N}$ may by 
itself be too slow to meet peak crop $\mathrm{N}$ demand at the onset of crop reproductive growth in mid-season.

Whether the accumulation of phenolic lignin residues and their binding with soil $\mathrm{N}$ leads to yield losses can depend on several factors. First, the amount of bound $\mathrm{N}$ must represent a sizable proportion of the labile $\mathrm{N}$ pool. We hypothesize that of the organic $\mathrm{N}$ that is covalently bound by lignin residues during a cropping period, much is mineralized at late crop growth stages or during the fallow, so that the total amount of covalently bound $\mathrm{N}$ increased only gradually during consecutive seasons of continuous cropping. After sufficient number of cropping periods it becomes a significant proportion of total $\mathrm{N}$, and only then will its delayed mineralization significantly inhibit soil $\mathrm{N}$ supply and grain yield. The length of time until the onset of yield loss can depend on soil type, e.g. the amount of SOM in the soil. For example, the yield decline of continuous rice experiments in the Philippines became apparent only after several consecutive rice crops (Cassman et al., 1995), and the soils were rich in SOM. In the low $\mathrm{C}$ rice soils of Arkansas, a yield gap was established near the outset of continuous rice cropping (Anders et al., 2004).

A second consideration is that the chemical stabilization causes only a partial blockage of the soil $\mathrm{N}$ supply. Even after $30 \mathrm{y}$ of continuous double- or triple-cropping and a sizable yield decline, the soils in the Philippine long-term field experiments still supply appreciable quantities of $\mathrm{N}$ to the crop. For yield to be affected by a partial blockage of the soil $\mathrm{N}$ supply, no factor other than $\mathrm{N}$ can constrain yield, including pests, low solar radiation, poor crop establishment, drought, or deficiencies or toxicities of other nutrients. Nitrogen fertilizer must be applied either at inadequate rates or in a timing that is dissynchronous with crop $\mathrm{N}$ demand. For several long-term field experiments in tropical Asia in which the initial yields of continuous lowland rice were well below the yield potentials, yield declines were less striking than for experiments in which initial yield levels approached the yield potential (Dawe et al., 2000), suggesting that the initially low yields may have been constrained from the outset by factors unrelated to $\mathrm{N}$ supply. Farmers' yields are normally well below the yield potentials, due to any or all of the constraints listed above. Therefore we cannot estimate the impact of covalently bound $\mathrm{N}$ on total rice production in Asia nor the benefit that could be gained through improved availability of soil $\mathrm{N}$.

Third, $\mathrm{N}$ mineralization can be affected by the general chemical nature of SOM, not merely its enrichment with phenols. In extremely young SOM, e.g., abundant levels of labile $\mathrm{N}$ appear to enable high rates of $\mathrm{N}$ mineralization despite the presence of phenolic lignin residues. The small MHA fraction of the PRRI soil (Fig. 3) was highly enriched in young, labile compounds such as nitrogenous compounds (Olk et al., 1998) and was more easily mineralized than was the MHA of the IRRI soil (Nguyen et al., 2004). Nevertheless, CP/MAS ${ }^{13} \mathrm{C}$ NMR spectra showed comparable phenol peaks for the MHA from both soils (Olk et al., 1998). In an extremely young fraction such as the MHA of the PRRI soil, the lignin might not have yet been degraded sufficiently to promote its chemical binding with soil organic $\mathrm{N}$.

\subsection{Mitigation options}

In anaerobic agroecosystems where covalent binding by lignin residues is shown to inhibit $\mathrm{N}$ supply and impair crop yield trends, an obvious option for field management is to introduce soil aeration by growing upland crops. This option is not economically viable, though, for all farmers. A more widely applicable approach is to apply $\mathrm{N}$ fertilizer several times during the growing season and at rates that synchronize $\mathrm{N}$ supply with crop $\mathrm{N}$ demand. This approach compensates for the decreased availability of soil $\mathrm{N}$ by increasing the availability of fertilizer $\mathrm{N}$ (Cassman et al., 1995). Yield losses can be reversed but at greater costs of fertilizer and labor.

Another approach that may alleviate the yield constraint is to modify key management practices of the anaerobic cropping so that phenolic lignin residues do not accumulate in soil. Evidence from the Philippines study indicated that anaerobic decomposition of crop residues is the key feature that promotes accumulation of lignin residues in anaerobic soils, and this is consistent with the fact that crop residues are the main parent material of new SOM. Further field evaluation of aerobic decomposition is needed in a wider range of field conditions to determine whether aerobic decomposition effectively promotes formation of phenol-depleted SOM so that in-season mineralization of soil $\mathrm{N}$ is unimpeded even during flooded conditions.

Aerobic decomposition could be accomplished by draining the field at any of several crop growth stages. Drainage early in the growing season would coincide with much of the crop residue decomposition. Rice farmers in Japan typically drain their fields during later crop growth stages because of the visible benefits to crop $\mathrm{N}$ uptake. Intermittent drainage is compatible with proposed solutions for emerging concerns of water availability in tropical Asia (Bouman et al., 2002) and Arkansas rice lands. Alternatively, in the Philippines field evaluation of aerobic decomposition, crop residues were incorporated at the beginning of the fallow period, instead of at its end.

In situations where covalent binding of soil $\mathrm{N}$ does not threaten yield trends, its prevention might still provide agronomic benefits, because covalent binding would appear to result in less efficient crop uptake of soil $\mathrm{N}$. Avoidance of covalent binding promises timelier mineralization of soil $\mathrm{N}$, enabling a reduction in rates of $\mathrm{N}$ fertilizer application while maintaining yield targets.

\section{Acknowledgments}

The authors thank Joven Alcantara, Josue Descalsota, Pete Gapas, Edsel Moscoso, and Marianne Samson of IRRI for their dedicated research in field and laboratory 
studies and Jason Grantham and Jared Holzhauer for their contributions at the University of Arkansas Rice Research and Extension Center.

\section{References}

Anders, M.M., Olk, D., Harper, T., Daniel, T., Holzhauer, J., 2004. The effect of rotation, tillage, and fertility on rice grain yields and nutrient flows. In: Proceedings, 26th Southern Conservation Tillage Conference for Sustainable Agriculture, 8-9 June 2004, Raleigh, North Carolina Agricultural Research Service, NC (CD format).

Balesdent, J., Chenu, C., Balabane, M., 2000. Relationship of soil organic matter dynamics to physical protection and tillage. Soil \& Tillage Research 53, 215-230.

Bandel, V.A., Dzienia, S., Stanford, G., Legg, J.O., 1975. N behavior under no-till vs. conventional corn culture. I. First-year results using unlabeled N fertilizer. Agronomy Journal 67, 782-786.

Benner, R., MacCubbin, A.E., Hodson, R.E., 1984. Anaerobic biodegradation of the lignin and polysaccharide components of lignocellulose and synthetic lignin by sediment microflora. Applied and Environmental Microbiology 47, 998-1004.

Bouman, B.A.M., Hengsdijk, H., Hardy, B., Bindraban, P.S., Tuong, T.P., Ladha, J.K., 2002. Water-wise rice production. Proceedings of the International Workshop on Water-wise rice production, 8-11 April 2002, Los Baños, Laguna, Philippines. International Rice Research Institute, Los Baños, Philippines, 356pp.

Cannell, R.Q., Hawes, J.D., 1994. Trends in tillage practices in relation to sustainable crop production with special reference to temperate climates. Soil \& Tillage Research 30, 245-282.

Carefoot, J.M., Nyborg, M., Lindwall, C.W., 1990. Differential fertilizer $\mathrm{N}$ immobilization in two tillage systems influences grain $\mathrm{N}$ concentration. Canadian Journal of Soil Science 70, 215-225.

Cassman, K.G., Pingali, P.L., 1995. Intensification of irrigated rice systems: learning from the past to meet future challenges. GeoJournal 35, 299-305.

Cassman, K.G., de Datta, S.K., Olk, D.C., Alcantara, J., Samson, M., Descalsota, J., Dizon, M., 1995. Yield decline and the nitrogen economy of long-term experiments on continuous, irrigated rice systems in the tropics. In: Lal, R., Stewart, B.A. (Eds.), Soil management: Experimental Basis for Sustainability and Environmental Quality. CRC/Lewis Publishers, Boca Raton, FL, pp. 181-222.

Clay, D.E., Malzer, G.L., Anderson, J.L., 1990. Tillage and dicyandiamide influence on nitrogen fertilizer immobilization, remineralization, and utilization by maize (Zea mays L. ). Biology and Fertility of Soils 9, 220-225.

Colberg, P.J., 1988. Anaerobic microbial degradation of cellulose, lignin, oligolignols, and monoaromatic lignin derivatives. In: Zehnder, A.J.B (Ed.), Biology of Anaerobic Microorganisms. Wiley, New York, pp. 333-372.

Dawe, D., Dobermann, A., Moya, P., Abdulrachman, S., Singh, B., Lal, P., Li, S.Y., Lin, B., Panaullah, G., Sariam, O., Singh, Y., Swarup, A., Tan, P.S., Zhen, Q.-X., 2000. How widespread are yield declines in long-term rice experiments in Asia? Field Crops Research 66, 175-193.

De Datta, S.K., Gomez, K.A., Descalsota, J.P., 1988. Changes in yield response to major nutrients and in soil fertility under intensive rice cropping. Soil Science 146, 350-358.

Dobermann, A., Dawe, D., Roetter, R.P., Cassman, K.G., 2000. Reversal of rice yield decline in a long-term continuous cropping experiment. Agronomy Journal 92, 633-643.

Evans, W.C., 1977. Biochemistry of the bacterial catabolism of aromatic compounds in anaerobic environments. Nature 270, 17-22.

Flaig, W., Beutelspacher, H., Rietz, E., 1975. Chemical composition and physical properties of humic substances. In: Gieseking, J.E. (Ed.), Soil Components. Volume 1. Organic Components. Springer, New York, pp. $1-211$.
Haider, K., Martin, J.P., Felip, Z., 1975. Humus biochemistry. In: Paul, E.A., McLaren, A.D. (Eds.), Soil biochemistry, Vol. 4. Marcel Dekker, NY, pp. 195-244.

Iragavarapu, T.K., Randall, G.W., 1995. Yield and nitrogen uptake of monocropped maize from a long-term tillage experiment on a poorly drained soil. Soil \& Tillage Research 34, 145-156.

Katase, T., 1993. Phenolic acids in tropical peats from peninsular Malaysia: Occurrence and possible diagenetic behavior. Soil Science 155, 155-165.

Keeney, D.R., Sahrawat, K.L., 1986. Nitrogen transformations in flooded rice soils. Fertilizer Research 9, 15-38.

Kitur, B.K., Smith, M.S., Blevins, R.L., Frye, W.W., 1984. Fate of ${ }^{15}$ Ndepleted ammonium nitrate applied to no-tillage and conventional tillage corn. Agronomy Journal 76, 240-242.

Knicker, H., Hatcher, P.G., 1997. Survival of protein in an organic-rich sediment: possible protection by encapsulation in organic matter. Naturwissenschaften 84, 231-234.

Knicker, H., Kögel-Knabner, I., 1998. Soil organic nitrogen formation examined by means of NMR spectroscopy. In: Stankiewicz, B.A., van Bergen, P.F. (Eds.), Nitrogen-Containing Macromolecules in the Bioand Geosphere. American Chemical Society, Washington, DC, pp. 339-356.

MacCarthy, P., 2001. The principles of humic substances. Soil Science 166, 738-751.

Mahieu, N., Olk, D.C., Randall, E.W., 2000. Accumulation of heterocyclic nitrogen in humified organic matter: a ${ }^{15} \mathrm{~N}-\mathrm{NMR}$ study of lowland rice soils. European Journal of Soil Science 51, 379-389.

Malcolm, R.L., 1990. Variations between humic substances isolated from soils, stream waters, and groundwaters as revealed by ${ }^{13} \mathrm{C}-\mathrm{NMR}$ spectroscopy. In: MacCarthy, P., Clapp, C.E., Malcolm, R.L., Bloom, P.R. (Eds.), Humic Substances in Soil and Crop Sciences: Selected Readings. American Society of Agronomy, Madison, WI, pp. 13-35.

Meisinger, J.J., Bandel, V.A., Stanford, G., Legg, J.O., 1985. Nitrogen utilization of corn under minimal tillage and moldboard plow tillage. I. Four-year results using labeled $\mathrm{N}$ fertilizer on an Atlantic coastal plain soil. Agronomy Journal 77, 602-611.

Mortland, M.M., Wolcott, A.R., 1965. Sorption of inorganic nitrogen compounds by soil materials. In: Bartholomew, W.V., Clark, F.E. (Eds.), Soil nitrogen. Nr 10. American Society of America, Madison, WI, pp. 150-197.

Nguyen BaoVe, Olk, D.C., Cassman, K.G., 2004. Nitrogen mineralization from humic acid fractions in rice soils depends on degree of humification. Soil Science Society of America Journal 68, 1278-1284.

Olk, D.C., Cassman, K.G., Randall, E.W., Kinchesh, P., Sanger, L.J., Anderson, J.M., 1996. Changes in chemical properties of organic matter with intensified rice cropping in tropical lowland soil. European Journal of Soil Science 47, 293-303.

Olk, D.C., Cassman, K.G., Mahieu, N., Randall, E.W., 1998. Conserved chemical properties of young humic acid fractions in tropical lowland soil under intensive irrigated rice cropping. European Journal of Soil Science 49, 337-349.

Olk, D.C., Brunetti, G., Senesi, N., 1999. Organic matter in doublecropped lowland rice soils: Chemical and spectroscopic properties. Soil Science 164, 633-649.

Olk, D.C., Brunetti, G., Senesi, N., 2000. Decrease in humification of organic matter with intensified lowland rice cropping: a wet chemical and spectroscopic investigation. Soil Science Society of America Journal 64, 1337-1347.

Olk D.C., Samson, M.I., Gapas, P., 2006. Inhibition of nitrogen mineralization in young humic fractions by anaerobic decomposition of rice crop residues. European Journal of Soil Science, in press.

Preston, C.M., 1996. Applications of NMR to soil organic matter analysis: history and prospects. Soil Science 161, 144-166.

Reddy, K.R., D’Angelo, E., Lindau, C., Patrick Jr., W.H., 1990. Urea losses in flooded soils with established oxidized and reduced soil layers. Biology and Fertilty of Soils 9, 283-287. 
Rice, C.W., Smith, M.S., Blevins, R.L., 1986. Soil nitrogen availability after long-term continuous no-tillage and conventional tillage corn production. Soil Science Society of America Journal 50, 1206-1210.

Schmidt-Rohr, K., Mao, J.-D., 2002a. Selective observation of nitrogenbonded carbons in solid-state NMR by saturation-pulse induced dipolar exchange with recoupling. Chemical Physics Letters 359, 403-411.

Schmidt-Rohr, K., Mao, J.-D., 2002b. Efficient CH-group selection and identification in ${ }^{13} \mathrm{C}$ solid-state NMR by dipolar DEPT and ${ }^{1} \mathrm{H}$ chemical-shift filtering. Journal of the American Chemical Society 124, 13938-13948.

Schmidt-Rohr, K., Mao, J.-D., Olk, D.C., 2004. Nitrogen-bonded aromatics in soil organic matter and their implications for a yield decline in intensive rice cropping. Proceedings of the National Academy of Sciences USA 101, 6351-6354.

Scott, H.D., Wood, L.S., 1989. Impact of crop production on the physical status of a Typic Albaqualf. Soil Science Society of America Journal 53, 1819-1825.
Stevenson, F.J., Cole, M.A., 1999. Cycles of Soil: Carbon, Nitrogen, Phosphorus, Sulfur, Micronutrients, Second ed. Wiley, New York 427pp.

Tate, R.L., 1979. Effect of flooding on microbial activities in organic soils: carbon metabolism. Soil Science 128, 267-273.

Thomas, G.W., Blevins, R.L., Phillips, R.E., McMahon, M.A., 1973. Effect of a killed sod mulch on nitrate movement and corn yield. Agronomy Journal 65, 736-739.

U.S. Department of Agriculture, 1975. USDA Agricultural Statistics 1975.

U.S. Department of Agriculture, 1980. USDA Agricultural Statistics 1980.

Verma, L., Martin, J.P., Haider, K., 1975. Decomposition of carbon-14labeled proteins, peptides, and amino acids: free and complexed with humic polymers. Soil Science Society of America Proceedings 39, 279-284.

Yoshida, S., 1981. Fundamentals of Rice Crop Science. International Rice Research Institute, Los Baños, Philippines. 